\title{
The effects of perceived ease of use, electronic word of mouth and content marketing on purchase decision
}

\author{
Asnawatia , Maryam Nadir ${ }^{\mathrm{a}}$, Wirasmi Wardhani ${ }^{\mathrm{a}}$, and Made Setini ${ }^{\mathrm{b} *}$
}

${ }^{a}$ Faculty of Economic and Business, Mulawarman University Samarinda, East Kalimantan, Indonesia ${ }^{b}$ Faculty of Economics and Business, Udayana University, Denpasar, Bali, Indonesia

\section{H R O N I C L E}

Article history:

Received: June 18, 2021

Received in revised format: July

29, 2021

Accepted: October 1, 2021

Available online: October 1, 2021

Keywords:

Brand image

Perceived ease of use

Electronic word of mouth

Content marketing

Purchasing decision

\section{Introduction}

Indonesia is confronted with many problems related to economic aspects because of Covid-19 pandemic. The impact of the declining percentage of the economy in Indonesia, one of which is the increase in unemployment and the poor caused by layoffs during the Covid-19 pandemic (Wang et al., 2021). However, this does not apply to online commerce, which is growing even more during the pandemic. The increasingly massive use of the internet has increased online transactions in Indonesia, supported by the Covid-19 pandemic, which forces all activities to be done at home. Traveloka as the object of this research is an airline and hotel reservation company that uses the concept of online-based marketing (Wijaya \& Susilo, 2021). One of the most popular e-commerce sites in Indonesia, Traveloka is ranked 97th in Indonesia as a popular website. Here are the 10 most popular travel agents. The results of the Daily Social survey in 2018 showed that consumers often use online agents to make their trips easier. They used it to make hotel and transportation reservations. Traveloka was the mainstay used by $70.37 \%$ of respondents. Tiket.com followed with the acquisition of $27.27 \%$ of respondents. The third and fourth positions were Airy Rooms and Agoda. They were used by $20.20 \%$ and $19.69 \%$ of consumers, respectively. DailySocial published its research results in the 2018 Startup Report. The survey on the use of online travel agencies was conducted in February last year. The number of respondents involved were as many as 2013 people (DailySocial, 2019). However, Traveloka has been affected by the Covid-19 pandemic. This is due to a decrease in the number of passengers using water, land, and air facilities.

* Corresponding author

E-mail address: made.setini@student.unud.ac.id (M. Setini)

(C) 2022 by the authors; licensee Growing Science, Canada. doi: $10.5267 /$ j.ijdns.2021.10.001 
According to the Indonesia National Air Carriers Association (INACA), the number of airplane passengers has decreased drastically due to the Covid-19 pandemic. When compared to 2019, there was a decrease in bookings for airline tickets and hotels in 2020. The following is the website traffic for Traveloka airline tickets and hotels, which have decreased (Utama et al., 2020). From January 2020 to April 2020, sales of airline tickets and hotels continued to decline drastically. This decrease in purchasing decision is due to the Covid-19 pandemic, which requires people to limit activities outside the home. To improve purchasing decisions, there are several things that need to be considered by Traveloka, such as making it easier to use the Traveloka application, increasing positive information about safe travel with good health protocols, and increasing content marketing through advertising on social media. The existence of the internet provides convenience in online buying and selling transactions. Therefore, the perceived ease of use is a determining factor for online purchasing decisions. This perceived ease of use will have an impact on behavior, namely the higher one's perception of the ease of using the system, the higher the level of utilization of information technology. People tend to prefer things which are instant, so it is likely that consumers will tend to use online shopping applications as a means to facilitate their activities that can be done anywhere and anytime (Chouk \& Mani, 2019; Mani \& Chouk, 2021). Research done by (Bonn et al., 2016; Wilson et al., 2021), shows that the perceived ease of use has a positive and significant impact on purchasing decisions. However, it contrasts with research conducted by (Bonn et al., 2016), which shows the result that the perceived ease of use does not have a significant impact on purchasing decisions. In addition, electronic word of mouth received by consumers through electronic media is a factor that determines consumer purchasing decisions. Electronic word of mouth is more effective than word of mouth communication in the offline world, because of greater accessibility and wider reach where consumers use the internet media with the aim of sharing their own experiences of a brand, product, or service that they have used (Siddiqui et al., 2021). Some studies conducted by (Kitirattarkarn et al., 2021); (Suhud, 2021); (Zhang et al., 2021) show that electronic word of mouth has a positive and significant impact on purchasing decisions. However, it contrasts with the research conducted by (Zhao et al., 2020); (Ekawati et al., 2020), which shows that electronic word of mouth has no significant effect on purchasing decisions. Moreover, content marketing also has an impact on purchasing decisions. According to (Hajarian et al., 2021), content marketing is something created or shared by individuals or organizations to tell a story like a conversation. Research conducted by (Mathew \& Soliman, 2021); (Yaghtin et al., 2020), shows the result that content marketing has a positive and significant impact on purchasing decisions. This result is inversely proportional to the research conducted by (Kamil \& Albert, 2020), which shows the result that content marketing does not have a significant influence on purchasing decision. Another thing that influences the purchasing decision is Brand Image. According to (Tsai, 2020), brand image is a perception about a brand which is a reflection of consumers' memory of their association with the brand. Traveloka is the e-commerce with the highest sales in Indonesia (Zahratu \& Hurriyati, 2020). In other words, Traveloka has a good brand image in the eyes of consumers. According to $\mathrm{Yi}$ and $\mathrm{Oh}$ (2021), consumers in making a purchasing decision, if they do not have experience with a product, they will tend to trust a preferred or well-known brand. This is the reason why brand image is used as a mediating variable. Research conducted by (Setini et al., 2020; Miandari et al., 2021; Al-Rawabdeh et al., 2021) shows that brand image can mediate the effect of electronic word of mouth on purchasing decisions. There are not many studies that use brand image as a mediating variable on the effect of perceived ease of use, electronic word of mouth and content marketing on purchasing decisions, so this is novel in this study. Based on this consideration, this study aims to find out on how brand image mediates the effect of perceived ease of use, electronic word of mouth and content marketing towards ticket purchasing decision on the Traveloka application.

\section{Literature Review}

\subsection{Purchasing Decision}

Purchasing decision is an integration process that combines knowledge to evaluate two or more alternative behaviors and choose one of them (Said et al., 2020; Fortunata \& Toni, 2020). In general, consumer purchasing decisions are to buy the most preferred brand (Dhiman et al., 2018). The indicators used are product choice, brand choice, time of purchase, number of products purchased and payment method. Purchase Decision is the process of selecting two or more alternative choices that result in a decision to buy or not to buy. Alternative options must be available when consumers will make a decision. The buying decision-making process requires seeking or receiving different information (Hildebrand \& Bergner, 2021). The process carried out to combine all the knowledge obtained by consumers into value considerations that are useful in choosing two or more alternatives, so that they can decide on one product (Miller et al., 2020). Purchase intentions could change if the situation faced by consumers inhibits or forces them to cancel the purchase or switch to other alternative choices (Diemer et al., 2020).

\subsection{Brand Image on Purchasing Decision}

According to Amoozad Mahdiraji et al. (2020), a good brand image can increase consumer brand loyalty, trust, and also the intention to buy products from the brands they trust. Therefore, brand image has a direct influence on product sales volume (Lutfie \& Marcelino, 2020). The indicators used are corporate image, user image and product image. Once upon a time having a good or well-known brand image is often seen as a quality product (Marques et al., 2020), thus providing the greatest positive influence on consumers' purchase intentions (Zhao et al., 2020), brand image has a positive impact on consumer purchase intention (Mao et al., 2020). According to (Febriyantoro, 2020; Al-Dmour et al., 2021) Brand Image has an effect on consumer purchase intentions, the stronger the product brand image, the greater the purchase intention. 


\subsection{Perceived Ease of Use on Brand Image and Purchasing Decision}

According to Bi and Kim (2020) and Park et al. (2020), perceived convenience is where consumers feel that shopping at webbased stores will increase their shopping and the extent to which consumers feel the ease of interaction with websites and can receive the product information they need. Online media users expect ease of use in their behavior (Pitafi et al., 2020; Min \& Lee, 2020). The indicators used are easy to use, easy to learn, controllable, clear and easy to understand and flexible. Perceived ease of use is a factor influencing reuse or addiction (Pitafi et al., 2020). Perceived usefulness is described as a person's tendency to use an application and believe that this perception will help him do a better job (Rezaei et al., 2020). The convenience felt by customers will give the color of the story so that it creates a brand image for a product or service (Byun et al., 2018; Pratama et al., 2019).

\subsection{Electronic Word of Mouth on Brand Image and Purchasing Decision}

Thurau et al. in ( Chen \& Dermawan, 2020; McLean et al., 2021) said electronic word of mouth is a statement made by actual, potential or previous consumers about a product or company in which this information is available to people or institutions through the internet. According to (Shrafat et al., 2021), in measuring the effect of electronic word of mouth, the indicators used are intensity, content, positive opinions and negative opinions. (Şehirli, 2020; Kamil \& Albert, 2020) Defines e-WOM as "any positive or" negative statement made by potential, current, or former customers about a product or company that is made available to many people and institutions via the Internet", trustworthy such as brand websites. (Reza Jalilvand \& Samiei, 2012) examines how e-WOM affects product choice using an experimental study of consumers' use of online recommendation sources. (Kajtazi \& Zeqiri, 2020; Mansour \& Farmanesh, 2020) shows that lack of effective information to differentiate products increases purchase risk. E-WOM will be a very important reference for consumers to build their purchasing decisionmaking process (Choi, 2020; Bu et al., 2021).

\subsection{Content Marketing on Brand Image and Purchasing Decision}

Based on research of Garcia et al. (2021), content marketing is a form of internet marketing in which the technique is to create and distribute useful and relevant content which aims to attract customers. According to (Ho et al., 2020), the dimensions of content marketing consist of the quality and quantity of information provided to consumers. The indicators used are relevant, accurate, easy to understand, easy to find and consistent. According to Holliman and Rowley (2014), Yodi et al. (2020) a marketer believes that content marketing is likely to have the biggest impact on their business in the near future. Branded content marketing, as a branch of brand communication, seeks to produce valuable information to satisfy consumer needs (Kowalska, 2016; Smith \& Brower, 2021). Content marketing has the same goals as advertising in terms of increasing sales and building a brand (Järvinen \& Taiminen, 2016; Lou \& Xie, 2021). Content marketing has been found to help brands build trust and credibility (Hussain et al., 2020; Xie \& Lou, 2021).

\section{Method}

This study employed a quantitative approach with non-experimental methods (no treatment or manipulation of research variables), that is a study in which the variables to be measured are inherent in the respondents, with data collection techniques that can be done by means of interview, questionnaire and observation. The data were analyzed using an analysis tool in the form of a Structural Equation Model (SEM) program through AMOS software. The sample was taken based on the multiplication of 5 variables with the number of 26 items, namely 130 samples who had purchased tickets online at Traveloka at least once.

\section{Result and Discussion}

\section{Table 1}

The summary of some descriptive statistics

\begin{tabular}{|c|c|c|c|c|c|}
\hline & $\mathrm{N}$ & Minimum & Maximum & Mean & Std. Deviation \\
\hline Perceived Ease of Use & 130 & 3 & 5 & 3.9 & 0.6 \\
\hline EWOM & 130 & 2 & 5 & 3.9 & 0.7 \\
\hline Content Marketing & 130 & 3 & 5 & 3.9 & 0.6 \\
\hline Brand Image & 130 & 3 & 5 & 4.1 & 0.7 \\
\hline Purchasing Decision & 130 & 3 & 5 & 4.1 & 0.6 \\
\hline
\end{tabular}

Source: Processed data, 2021

Based on the descriptive results of the variables studied, 130 samples on the perceived ease of use variable obtained average respondent's answer of 3.9, the electronic word of mouth variable with an average respondent's answer of 3.9, the content marketing variable with an average respondent's answer of 3.9, the brand image variable with an average respondent's answer of 4.1 and the purchasing decisions variable with an average respondent's answer of 4.1. The average respondent's answer on all variables is 4 , meaning that the respondent's perception of Traveloka based on the variables studied is good. PLS-SEM analysis of brand image mediates the effect of perceived ease of use, electronic word of mouth and content marketing towards ticket purchasing decision on the Traveloka application. PLS model evaluation is done by evaluating the outer model and 
inner model. The outer model is a measurement model to assess the validity and reliability of the model. Through the algorithm iteration process, the measurement model parameters (convergent validity, discriminant validity, composite reliability and Cronbach's alpha) were obtained, including the R2 value as a parameter for the accuracy of the prediction model. Inner model is a structural model to predict causality between latent variables.

\subsection{Outer Model (Measurement Model)}

In this research, validity and reliability tests were conducted on the latent variable indicators of brand image, perceived ease of use, electronic word of mouth, content marketing and purchasing decision using SmartPLS 3.2.0 software. Table 2 shows the output of the outer model.

Table 2

The results of outer model

\begin{tabular}{|c|c|c|c|c|c|}
\hline & PKP & $\mathrm{CM}$ & EWOM & BI & KP \\
\hline X1.1 & 0.850 & & & & \\
\hline X1.2 & 0.916 & & & & \\
\hline X1.3 & 0.833 & & & & \\
\hline X1.4 & 0.926 & & & & \\
\hline X1.5 & 0.903 & & & & \\
\hline CM1 & & 0.813 & & & \\
\hline CM2 & & 0.833 & & & \\
\hline CM3 & & 0.856 & & & \\
\hline CM4 & & 0.900 & & & \\
\hline CM5 & & 0.911 & & & \\
\hline X3.1 & & & 0.921 & & \\
\hline X3.2 & & & 0.898 & & \\
\hline X3.3 & & & 0.925 & & \\
\hline X3.4 & & & 0.872 & & \\
\hline Z1 & & & & 0.947 & \\
\hline $\mathbf{Z 2}$ & & & & 0.971 & \\
\hline $\mathbf{Z 3}$ & & & & 0.971 & \\
\hline Z4 & & & & 0.953 & \\
\hline Z5 & & & & 0.981 & \\
\hline Z6 & & & & 0.968 & \\
\hline Z7 & & & & 0.930 & \\
\hline Y1 & & & & & 0.796 \\
\hline Y2 & & & & & 0.811 \\
\hline Y3 & & & & & 0.840 \\
\hline Y4 & & & & & 0.868 \\
\hline Y5 & & & & & 0.828 \\
\hline
\end{tabular}

From Fig. 1 below, the loading factor $(\lambda)$ of the indicator values of each brand image construct, perceived ease of use, electronic word of mouth, content marketing and purchasing decision is $>0.7$. This means that it is valid to use, while the path coefficients of the construct of perceived ease of use to brand image of -0.223 , construct of content marketing to brand image of 0.820 , construct of electronic word of mouth to brand image of 0.202 , construct of perceived ease of use to purchasing decision of 0.337 , construct of content marketing to purchasing decision of -0.368 , the electronic word of mouth construct to the purchasing decision is 0.287 , the brand image construct to the purchasing decision is 0.604 . The R-Square possessed by the brand image construct is 0.644 ; the R-Square for the purchasing decision construct is 0.421 .

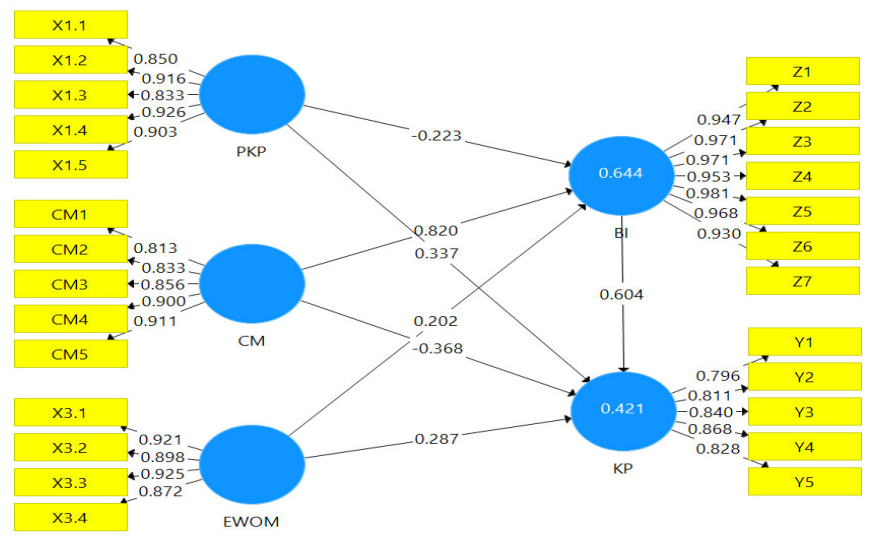

Fig. 1. The results of outer model 
The validity test is used to measure how strong the correlation between the construct and the question items is, as well as the relationship with other variables. What is usually used to assess validity is seen from the loading factor $>0.7, \mathrm{AVE}>0.5$ and cross loading $>0.7$ in one variable. According to Hair et al. (2011), the value of Cronbach's alpha and composite reliability must be greater than 0.7 .

Table 3

AVE, Cronbach's Alpha, Composite Reliability

\begin{tabular}{|c|c|c|c|}
\hline & AVE & Cronbach's Alpha & Composite Reliability \\
\hline Perceived Ease of Use & 0.786 & 0.932 & 0.948 \\
\hline Electronic Word of Mouth & 0.818 & 0.926 & 0.947 \\
\hline Content Marketing & 0.745 & 0.914 & 0.936 \\
\hline Brand Image & 0.922 & 0.986 & 0.988 \\
\hline Purchasing Decision & 0.687 & 0.886 & 0.916 \\
\hline
\end{tabular}

In Table 3, the results of data analysis show that all latent variables have AVE values, Cronbach's alpha and composite reliability above the specified prerequisites, meaning that the measurement model is acceptable, valid and reliable.

\subsection{Inner Model (Structural Model)}

The structural model in PLS is evaluated using R-Square (R2) for the dependent variable, while the path coefficients and Tcount values for each path are used to test the significance between variables in the model. The value of R2 is used to measure the level of variation of changes in the independent variable to changes in the dependent variable. The higher the R2 value, the better the prediction model of the research model. According to (Hair et al. 2011), the rule of thumb R2 value of 0.75 is considered strong, 0.50 is considered moderate and 0.25 is considered weak. Based on the results of data processing, the R2 value of the dependent variable brand image and purchasing decision can be said to be moderate, as presented in Table 4 .

Table 4

R-square

\begin{tabular}{|c|c|c|}
\hline & R Square & Interpretation \\
\hline Brand Image & 0.644 & Moderate \\
\hline Purchasing Decision & 0.421 & Moderate \\
\hline
\end{tabular}

Through the value of the coefficient of determination (R-square) contained in the table above, it can be seen in the first substructure that the R-Square value of the brand image variable is 0.644 , which shows that brand image can be explained by $64.4 \%$ by the perceived ease of use variable, electronic word of mouth and content marketing. In the second substructure, the R-square value of the purchasing decision variable is 0.421 , which indicates that the purchasing decision can be explained by $42.1 \%$ by the perceived ease of use, electronic word of mouth, content marketing and brand image variables.

Hypotheses testing is done by looking at the results of bootstrapping on the path coefficients by comparing the T-count with the T-table (1.96). If T-count > T-Table then the hypothesis (H1) is accepted. The results of data analysis with 5\% alpha are presented in Table 5.

Table 5

Results of Hypotheses Testing

\begin{tabular}{|c|c|c|c|c|}
\hline & Path & T-Count & Hypothesis & Conclusion \\
\hline Perceived Ease of Use $\rightarrow$ Brand Image & -0.223 & 4.002 & Accepted & Significant \\
\hline Content marketing $\rightarrow$ Brand Image & 0.820 & 14.054 & Accepted & Significant \\
\hline EWOM $\rightarrow$ Brand Image & 0.202 & 3.590 & Accepted & Significant \\
\hline Perceived Ease of Use $\rightarrow$ Purchasing Decision & 0.337 & 3.665 & Accepted & Significant \\
\hline Content marketing $\rightarrow$ Purchasing Decision & -0.368 & 3.091 & Accepted & Significant \\
\hline EWOM $\rightarrow$ Purchasing Decision & 0.287 & 3.526 & Accepted & Significant \\
\hline Brand Image $\rightarrow$ Purchasing Decision & 0.604 & 5.407 & Accepted & Significant \\
\hline Perceived Ease of Use $\rightarrow$ Brand Image $\rightarrow$ Purchasing Decision & -0.135 & 2.929 & Accepted & Significant \\
\hline Content Marketing $\rightarrow$ Brand Image $\rightarrow$ Purchasing Decision & 0.495 & 4.974 & Accepted & Significant \\
\hline EWOM $\rightarrow$ Brand Image $\rightarrow$ Purchasing Decision & 0.122 & 3.080 & Accepted & Significant \\
\hline
\end{tabular}

Based on the results of the evaluation of the inner model, the researcher concludes the research hypotheses. The results of hypotheses testing are as follows:

\section{The first hypothesis: The effect of perceived ease of use on brand image}

The calculation results show that the perceived ease of use has a negative and significant effect on brand image. According to (Pitafi et al., 2020; Min \& Lee, 2020), they suggest that brand image represents the overall perception of the brand which is 
formed from information and past experiences of the brand. The results of the study show a negative direction, meaning that when the perceived ease of use is good by consumers, the brand image decreases. This is due to the Covid-19 pandemic, in which many people have been forced to cancel their travel plans or tours. The flight or hotel tickets that they had booked on the Traveloka application had to be cancelled. According to (Zahratu \& Hurriyati, 2020), in December 2019 flight and hotel ticket sales increased, but decreased drastically in 2020 due to the large number of flight ticket cancellations. Regarding this, there was a problem with refunds for compensation to consumers, which caused Traveloka's brand image to decline (Rezaei et al., 2020; Miller et al., 2020). This means that a good brand image does not necessarily make consumers believe even though consumer perceptions are good. Teveloka is the most popular e-commerce with the highest level of sales before the Covid-19 pandemic. However, the current pandemic conditions and negative reviews from consumers have caused the brand image to decline. According to Pitafi et al. (2020), Online reviews are positive or negative statements about a product.

\section{The second hypothesis: The effect of electronic word of mouth on brand image}

The calculation results show that electronic word of mouth has a positive and significant effect on brand image. This means that when good information is provided to consumers, the brand image increases. Electronic Word of Mouth that is posted interactively has a strong effect on Brand Image. Electronic Word of Mouth is also one of the factors that greatly affect brand image (Şehirli, 2020; Kamil \& Albert, 2020). The frequency of consumers in receiving positive and negative information about Traveloka in electronic media affects the brand image. Information content regarding ticket prices, hotel rates that are always updated will affect the brand image (Shrafat et al., 2021). Indicators of intensity, content, positive and negative opinions can affect the brand image. This is in line with the research conducted by Reza Jalilvand and Samiei (2012), which shows the results that electronic word of mouth shows positive and significant results on brand image.

\section{The third hypothesis: The effect of content marketing on brand image}

The calculation results show that content marketing has a positive and significant impact on brand image. Building a positive brand can be obtained by creating a strong marketing program for these products, so that the products have unique characteristics and have advantages that are highlighted, which can make them different from other products (Ho et al., 2020). This means that there is a positive influence of content marketing on brand image.

The more often information in the form of advertisements is given to consumers; the more consumers will remember the brand image. Accurate information on the Traveloka application affects the brand image. The Traveloka application, which is easy to find on electronic media, causes it to be remembered by consumers, which in turn affects the brand image. According to Holliman and Rowley (2014) and Yodi et al. (2020), social media has changed the way organizations do business online in the past and, as a result, social media marketing has created its own marketplace in the business world, meaning it can lift brands quickly. Relevant indicators such as accuracy, easy to understand, easy to find and consistent are things that can affect brand image. This is in line with the research conducted by (Kowalska, 2016; Smith \& Brower, 2021), which shows that social media marketing has a positive and significant effect on brand image.

\section{The fourth hypothesis: The effect of perceived ease of use on purchasing decisions}

The calculation results show that the perceived ease of use has a significant influence on purchasing decisions (Diemer et al., 2020). Indicators in perceived ease of use such as easy to use, easy to learn, controllable, clear and easy to understand and flexible are things that can influence purchasing decisions (Byun et al., 2018). The easy-to-use and accessible Traveloka application causes consumers to choose the application to transact to buy tickets. This is in line with the research conducted by (Pratama et al., 2019), which show that the perceived ease of use has a positive and significant influence on purchasing decisions.

\section{The fifth hypothesis: The effect of electronic word of mouth on purchasing decisions}

The calculation results show that electronic word of mouth has a positive and significant influence on purchasing decisions. The large number of Traveloka IG followers who "like" their posts, causes consumers to make decisions to transact on the Traveloka application (Kajtazi \& Zeqiri, 2020). Positive comments on social media can also affect purchasing decisions. Consumer reviews about Traveloka via Twitter regarding the issue of refunds during the Covid-19 pandemic will be taken into consideration by consumers making purchasing decisions on the Traveloka application (Choi, 2020). Indicators of intensity, content, positive and negative opinions can affect purchasing decisions, that is when the information received by consumers is good for a product or service, the possibility of consumer purchasing decision will increase. This is in line with research conducted by (Bu et al., 2021). Several studies have been conducted by (Mansour \& Farmanesh, 2020; Şehirli, 2020; Kamil \& Albert, 2020), which show that electronic word of mouth has a significant influence on purchasing decisions.

\section{The sixth hypothesis: The effect of content marketing on purchasing decisions}

The calculation results show that content marketing has a negative and significant influence on purchasing decisions. During the Covid-19 pandemic, in which the accuracy of the content marketing of the Traveloka application was good, it resulted in a decrease in purchasing decisions. The purpose of content marketing to attract audiences to buy tickets on the Traveloka 
application did not succeed in increasing purchases. This is due to the large number of consumers who cancel flight tickets or hotel reservations. This is in line with the research conducted by (Kowalska, 2016; Smith \& Brower, 2021; Järvinen \& Taiminen, 2016; Lou \& Xie, 2021), which shows that content marketing has a significant impact on purchasing decisions. The positive or negative impact received by consumers depends on the information obtained by consumers.

\section{The seventh hypothesis: The effect of brand image on purchasing decisions}

The calculation results show that brand image has a positive and significant influence on purchasing decisions. Indicators on brand image such as company image, user image and product image are things that influence purchasing decisions. A good image of Traveloka as an application to buy tickets online has a positive effect on purchasing decisions. This is in line with the research conducted by (Lutfie \& Marcelino, 2020; Marques et al., 2020; Febriyantoro, 2020; Al-Dmour et al., 2021), that brand image has a positive and significant effect on purchasing decisions.

\section{The eight hypothesis: The mediating effect of brand image on the effect of perceived ease of use on purchasing decisions}

The calculation results show that there is a negative and significant effect of perceived ease of use on purchasing decisions through brand image, which means that brand image can mediate the relationship between perceived ease of use and purchasing decision. The previous hypothesis shows that perceived ease of use directly has a negative and significant influence on purchasing decisions, so this has an indirect influence on the effect of perceived ease of use towards purchasing decisions. When the brand image does not represent a good picture in the minds of consumers, there will be a decrease in purchasing decisions, even though the perceived ease of use in the Traveloka application has been good. According to Byun et al. (2018) and Pratama et al. (2019), the information received can influence consumers in imaging a brand, which can influence consumers to make purchases or not.

The ninth hypothesis: The mediating effect of brand image on the effect of electronic word of mouth on purchasing decisions

The calculation results show that there is a positive and significant effect of electronic word of mouth on purchasing decisions through brand image, which means that brand image can mediate the relationship between electronic word of mouth and purchasing decisions. Consumer reviews about Traveloka on social media affect the brand image which in turn affects purchasing decisions. Brand image is good or bad according to the information or reviews discussed. This is in line with research conducted by Kajtazi and Zeqiri (2020) and Mansour and Farmanesh (2020), shows that Brand image is able to mediate the influence of electronic word of mouth on purchasing decisions.

\section{The tenth hypothesis: The mediating effect of brand image on the effect of content marketing on purchasing decision}

The calculation results show that there is a positive and significant influence of content marketing on purchasing decisions through brand image, which means that brand image can mediate the relationship between content marketing and purchasing decision. The accuracy of the content marketing of the Traveloka application affects the brand image, which in turn affects the consumer's decision to buy tickets on the Traveloka application. According to (Järvinen \& Taiminen, 2016; Lou \& Xie, 2021), it was found that Instagram social media had a significant effect on the visiting decision process with destination image as a mediating variable. This is supported by the research conducted by (Hussain et al., 2020; Xie \& Lou, 2021), which shows that social media marketing has a positive and significant effect on consumer purchasing decisions mediated by brand image.

\section{Conclusion}

Research conducted on 130 respondents using the Traveloka application shows that perceived ease of use has a negative impact on purchasing decisions, either directly or indirectly through brand image. Meanwhile, electronic word of mouth has a positive impact on purchasing decisions, either directly or indirectly through brand image. Content marketing has a negative and significant impact on purchasing decisions, while indirectly through brand image has a positive and significant impact. Brand image can mediate the effect of perceived ease of use, electronic word of mouth and content marketing towards ticket purchasing decisions on the Taveloka application. A strong brand image will improve purchasing decisions which in turn will form consumer loyalty. Therefore, it is appropriate if brand image is used as a mediating variable.

\section{References}

Al-Dmour, H., Aloqaily, A., Al-Qaimari, R., \& Al-Hassan, M. (2021). The effect of the electronic word of mouth on purchase intention via the brand image as a mediating factor: an empirical study. International Journal of Networking and Virtual Organisations, 24(2), 182-199. https://doi.org/10.1504/IJNVO.2021.114732

Al-Rawabdeh, H., Ghadir, H., \& Al-Abdallah, G. (2021). The effects of user generated content and traditional reference groups on purchase intentions of young consumers: A comparative study on electronic products. International Journal of Data and Network Science, 5(4), 691-702.

Aghekyan-Simonian, M., Forsythe, S., Kwon, W. S., \& Chattaraman, V. (2012). The role of product brand image and online store image on perceived risks and online purchase intentions for apparel. Journal of Retailing and Consumer Services, 19(3), 325-331. https://doi.org/10.1016/j.jretconser.2012.03.006 
Amoozad Mahdiraji, H., Hafeez, K., Kord, H. and Abbasi Kamardi, A. (2020). Analysing the voice of customers by a hybrid fuzzy decision-making approach in a developing country's automotive market. Management Decision, Vol. ahead-of-print No. ahead-of-print. https://doi.org/10.1108/MD-12-2019-1732

Bonn, M. A., Kim, W. G., Kang, S., \& Cho, M. (2016). Purchasing wine online: The effects of social influence, perceived usefulness, perceived ease of use, and wine involvement. Journal of Hospitality Marketing \& Management, 25(7), 841869.

Bi, Y., \& Kim, I. (2020). Older Travelers' E-Loyalty: The Roles of Service Convenience and Social Presence in Travel Websites. Sustainability, 12(1), 410. https://doi.org/10.3390/su12010410

Bu, Y., Parkinson, J., \& Thaichon, P. (2021). Digital content marketing as a catalyst for e-WOM in food tourism. Australasian Marketing Journal, 29(2), 142-154.

Byun, H., Chiu, W., \& Bae, J. S. (2018). Exploring the adoption of sports brand apps: An application of the modified technology acceptance model. International Journal of Asian Business and Information Management (IJABIM), 9(1), 52-65.

Chouk, I. and Mani, Z. (2019). Factors for and against resistance to smart services: role of consumer lifestyle and ecosystem related variables. Journal of Services Marketing, Vol. 33 No. 4, pp. 449-462. https://doi.org/10.1108/JSM-01-2018-0046

Chen, J. L., \& Dermawan, A. (2020). The Influence of YouTube Beauty Vloggers on Indonesian Consumers' Purchase Intention of Local Cosmetic Products. International Journal of Business and Management, 15(5), 100-116.

Choi, J. (2020). HOW CONSUMERS ENGAGE IN \& UTILIZE THE SOURCE OF ELECTRONIC WORD-OF-MOUTH (e-WOM)?. Academy of Strategic Management Journal, 19(2), 1-12.

Daylysocial. Online Travel Agencies (OTA) survey 2018. Vailable online: https://dailysocial.id/research/online-travel-agencies-ota-survey-2018 (Accesed 20 September 2021)

Diemer, N., Staudacher, P., Atuhaire, A., Fuhrimann, S., \& Inauen, J. (2020). Smallholder farmers' information behavior differs for organic versus conventional pest management strategies: A qualitative study in Uganda. Journal of cleaner production, 257, 120465.

Dhiman, R., Chand, P. K., \& Gupta, S. (2018). Behavioural aspects influencing decision to purchase apparels amongst young Indian consumers. FIIB Business Review, 7(3), 188-200.

Ekawati, N., Yasa, N., Kusumadewi, N., \& Setini, M. (2021). The effect of hedonic value, brand personality appeal, and attitude towards behavioral intention. Management Science Letters, 11(1), $253-260$. https://doi.org/10.5267/j.msl.2020.8.008

Fortunata, R., \& Toni, N. (2020). The influence of service quality, tuition fee and promotion on student decisions to continue study in postgraduate of prima indonesia university. Budapest International Research and Critics Institute-Journal (BIRCI-Journal), 829-837.

Febriyantoro, M. T. (2020). Exploring YouTube Marketing Communication: Brand awareness, brand image and purchase intention in the millennial generation. Cogent Business \& Management, 7(1), 1787733.

Garcia, J. E., Pereira, J. S., \& Cairrão, Á. (2021). Social media content marketing strategy for Higher Education: a case study approach. In Marketing and Smart Technologies (pp. 493-505). Springer, Singapore.

Ho, J., Pang, C. and Choy, C. (2020). Content marketing capability building: a conceptual framework. Journal of Research in Interactive Marketing, 14(1), 133-151. https://doi.org/10.1108/JRIM-06-2018-0082

Hussain, S., Melewar, T. C., Priporas, C. V., Foroudi, P., \& Dennis, C. (2020). Examining the effects of celebrity trust on advertising credibility, brand credibility and corporate credibility. Journal of Business Research, 109, 472-488.

Holliman, G. and Rowley, J. (2014). Business to business digital content marketing: marketers' perceptions of best practice. Journal of Research in Interactive Marketing, 8(4), 269-293. https://doi.org/10.1108/JRIM-02-2014-0013

Hildebrand, C., \& Bergner, A. (2021). Conversational robo advisors as surrogates of trust: onboarding experience, firm perception, and consumer financial decision making. Journal of the Academy of Marketing Science, 49(4), 659-676.

Horváth, C. and Birgelen, M.v. (2015). The role of brands in the behavior and purchase decisions of compulsive versus noncompulsive buyers. European Journal of Marketing, 49(1/2), 2-21. https://doi.org/10.1108/EJM-10-2012-0627

Hajarian, M., Camilleri, M.A., Díaz, P. and Aedo, I. (2021). A Taxonomy of Online Marketing Methods. Camilleri, M.A. (Ed.) Strategic Corporate Communication in the Digital Age, Emerald Publishing Limited, Bingley, pp. 235-250. https://doi.org/10.1108

Järvinen, J., \& Taiminen, H. (2016). Harnessing marketing automation for B2B content marketing. Industrial Marketing Management, 54, 164-175.

Kamil, N. A. I., \& Albert, A. (2020). The effect of e-wom and brand image towards Sushi Masa consumer purchasing decision. Journal of Social Studies (JSS), 16(1), 19-34.

Kowalska, M. (2016). Influence of the Context Marketing on the Effectiveness of the Content Marketing. Handel Wewnętrzny, 364(5), 128-136.

Kajtazi, K., \& Zeqiri, J. (2020). The effect of e-WOM and content marketing on customers' purchase intention. International Journal of Islamic Marketing and Branding, 5(2), 114-131. https://doi.org/10.1504/IJIMB.2020.111144

Kitirattarkarn, G.P., Tao, W., \& Tsai, W.-H.S. (2021). Intended audience and valence of electronic word-of-mouth on social media: a study of Dutch consumers. Internet Research, 31(3), 990-1017. https://doi.org/10.1108/INTR-03-2020-0133

Lutfie, H., \& Marcelino, D. (2020). Creating online purchase decision and brand image based on advertising effectiveness with epic model. Jurnal Ilmiah Manajemen, 10(3), 346-366.

Lou, C., \& Xie, Q. (2021). Something social, something entertaining? How digital content marketing augments consumer experience and brand loyalty. International Journal of Advertising, 40(3), 376-402. 
Mani, Z., \& Chouk, I. (2021). Creation and destruction of the perceived value of a smart service: application to banking. Decisions Marketing, 2, 229-246.

McLean, G., Osei-Frimpong, K., \& Barhorst, J. (2021). Alexa, do voice assistants influence consumer brand engagement?Examining the role of AI powered voice assistants in influencing consumer brand engagement. Journal of Business Research, 124, 312-328. https://doi.org/10.1016/j.jbusres.2020.11.045

Mao, Y., Lai, Y., Luo, Y., Liu, S., Du, Y., Zhou, J., ... \& Bonaiuto, M. (2020). Apple or Huawei: understanding flow, brand image, brand identity, brand personality and purchase intention of smartphone. Sustainability, $12(8), 3391$. https://doi.org/10.3390/su12083391

MIN, S. R., \& LEE, S. M. (2020). A study on the behavior of the user according to the distribution development of online travel agency. The Journal of Distribution Science, 18(6), 25-35.

Miandari, G. A. K. D. D., Yasa, N. N. K., Wardana, M., Giantari, I. G. A. K., \& Setini, M. (2021). Application of Technology Acceptance Model to Explain Repurchase Intention in Online Shopping Consumers. Webology, 18(1).

Mathew, V., \& Soliman, M. (2021). Does digital content marketing affect tourism consumer behavior? An extension of $t$ echnology acceptance model. Journal of Consumer Behaviour, 20(1), 61-75.

Mansour, O., \& Farmanesh, P. (2020). Does gender matter? Acceptance and forwarding of electronic word of mouth: A moderated mediation analysis. Management Science Letters, 10(7), 1481-1486.

Marques, C., da Silva, R. V., Davcik, N. S., \& Faria, R. T. (2020). The role of brand equity in a new rebranding strategy of a private label brand. Journal of Business Research, 117, 497-507. https://doi.org/10.1016/j.jbusres.2020.06.022

Miller, C. J., Wiltsey-Stirman, S., \& Baumann, A. A. (2020). Iterative Decision-making for Evaluation of Adaptations (IDEA): A decision tree for balancing adaptation, fidelity, and intervention impact. Journal of Community Psychology, 48(4), 1163-1177.

Pratama, R. I., Megadini, D. D., \& Kusriandini, T. (2019). Effect of perceived ease of use, word-of-mouth communication, and brand image on decision to use Lazada E-commerce services. International Journal of Multicultural and Multireligious Understanding, 6(1), 173-186.

Pitafi, A. H., Kanwal, S., \& Khan, A. N. (2020). Effects of perceived ease of use on SNSs-addiction through psychological dependence, habit: The moderating role of perceived usefulness. International Journal of Business Information Systems, 33(3), 383-407.

Reza Jalilvand, M. and Samiei, N. (2012). The effect of electronic word of mouth on brand image and purchase intention: An empirical study in the automobile industry in Iran. Marketing Intelligence \& Planning, 30(4), 460-476. https://doi.org/10.1108/02634501211231946

Rezaei, R., Safa, L., \& Ganjkhanloo, M. M. (2020). Understanding farmers' ecological conservation behavior regarding the use of integrated pest management-an application of the technology acceptance model. Global Ecology and Conservation, 22, e00941. https://doi.org/10.1016/i.gecco.2020.e00941

Setini, M., Asih, D., Yasa, N., Utami, N., \& Giantari, I. (2020). The role of brand image in mediating the influence of customer perceived value on the loyalty of facebook users. Journal of Advanced Research in Dynamical \& Control Systems, 12(5), 1284-1293.

Smith, K. T., \& Brower, T. R. (2012). Longitudinal study of green marketing strategies that influence Millennials. Journal of Strategic Marketing, 20(6), 535-551.

Shrafat, F., Zeglat, D., Ensour, W., \& Sarhan, N. M. (2021). Analysis of the factors that influence adoption of information from managerial responses to negative electronic word-of-mouth. International Journal of Services and Operations Management, 39(4), 495-527.

Şehirli, M. (2021). Transformation of WOM (Word of Mouth) From Traditional to Digital and Current Recommendations for e-WOM. In Handbook of Research on IoT, Digital Transformation, and the Future of Global Marketing (pp. 380-400). IGI Global.

Siddiqui, M. S., Siddiqui, U. A., Khan, M. A., Alkandi, I. G., Saxena, A. K., \& Siddiqui, J. H. (2021). Creating Electronic Word of Mouth Credibility through Social Networking Sites and Determining Its Impact on Brand Image and Online Purchase Intentions in India. Journal of Theoretical and Applied Electronic Commerce Research, 16(4), 1008-1024. https://doi.org/10.3390/jtaer16040057

Said, S., Gani, A. A., Taufan, R. R., Syahnur, M. H., \& Basalamah, J. (2020). Green Marketing Practice In Purchasing Decision Home Care Product. International Journal Of Scientific \& Technology Research, 9(06), 893-896.

Suhud, U. (2021). Influence of Social Media Marketing, Electronic Word of Mouth and Consumer Engagement to Brand Loyalty in Indonesia Grab Company. International Journal of Business and Social Science Research, 2(2), 16-26.

Tsai, T. H., Wong, A. M., Lee, H. F., \& Tseng, K. C. (2020). The Influence of Brand Image on Brand Extension Evaluation: Design of the Living Intention Service Model and Brand Positioning of a Retirement Community. Sustainability, 12(18), 7478. https://doi.org/10.3390/su12187478

Utama, R., Bagus, I. G., Ruspendi Junaedi, I. W., Krismawintari, D., Putu, N., Pramono, J., \& Laba, I. N. (2020). New Normal Acceleration Strategy for Bali Tourism Destination Recovery with E-Tourism and Special Health Protocol for the Tourism Sector. Technium Society Science Journal, 10, 156.

Wang, C., Wang, D., Abbas, J., Duan, K., \& Mubeen, R. (2021). Global financial crisis, smart lockdown strategies, and the COVID-19 spillover impacts: A global perspective implications from Southeast Asia. Frontiers in Psychiatry, 12. 
Wijaya, O. R. C., \& Susilo, C. L. (2021). THE INFLUENCE OF TECHNOLOGY ACCEPTANCE MODEL (TAM) AND BRAND TRUST TOWARD CONSUMER'S INTENTION TO BUY IN TIKET. COM WITH E-WOM AS A MODERATING VARIABLE. JOURNAL OF TOURISM, CULINARY AND ENTREPRENEURSHIP (JTCE), 1(1), 15-24.

Wilson, N., Alvita, M., \& Wibisono, J. (2021). The Effect of Perceived Ease of Use and Perceived Security Toward Satisfaction and Repurchase Intention. Jurnal Muara Ilmu Ekonomi dan Bisnis, 5(1), 145-159.

Xie, Q., \& Lou, C. (2020). Curating Luxe experiences online? Explicating the mechanisms of luxury content marketing in cultivating brand loyalty. Journal of Interactive Advertising, 20(3), 209-224.

Yi, J., \& Oh, Y.K. (2021). Does brand type affect what consumers discuss? A comparison of attribute-based reviews of value and premium brands of an innovative product. Internet Research, Vol. ahead-of-print No. ahead-of-print. https://doi.org/10.1108/INTR-08-2020-0478

Yodi, H. P., Widyastuti, S., \& Noor, L. S. (2020). The effects of content and influencer marketing on purchasing decisions of fashion erigo company. Dinasti International Journal of Economics, Finance \& Accounting, 1(2), 345-357. https://doi.org/10.38035/dijefa.v1i2.309

Yaghtin, S., Safarzadeh, H., \& Karimi Zand, M. (2020). Planning a goal-oriented B2B content marketing strategy. Marketing Intelligence \& Planning, 38(7), 1007-1020. https://doi.org/10.1108/MIP-11-2019-0559

Younis, R.A.A., \& Hammad, R. (2021). Employer image, corporate image and organizational attractiveness: the moderating role of social identity consciousness. Personnel Review, 50(1), 244-263. https://doi.org/10.1108/PR-02-2019-0058

Zhang, Y., Zhang, J., \& Liu, C. (2021). Motives for Employees Communicate Positive Electronic Word of Mouth (eWOM) on Social Network Sites: Exploring Moderating Mechanisms. Australasian Marketing Journal, 1839334921999475.

Zhao, Y., Wang, L., Tang, H., \& Zhang, Y. (2020). Electronic word-of-mouth and consumer purchase intentions in social ecommerce. Electronic Commerce Research and Applications, 41, 100980. https://doi.org/10.1016/j.elerap.2020.100980

Zahratu, S. A., \& Hurriyati, R. (2020, February). Electronic Word of Mouth and Purchase Intention on Traveloka. In 3rd Global Conference On Business, Management, and Entrepreneurship (GCBME 2018) (pp. 33-36). Atlantis Press.

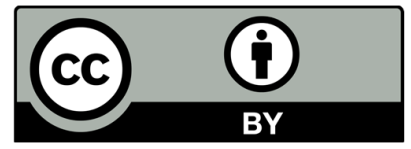

(C) 2022 by the authors; licensee Growing Science, Canada. This is an open access article distributed under the terms and conditions of the Creative Commons Attribution (CC-BY) license (http://creativecommons.org/licenses/by/4.0/). 